of patients. The mechanism through which the changed excipient exerted its effects did not appear to be an oddity of metabolism restricted to a few patients but seemed to be a common, if not a general, phenomenon among epileptics. This view was supported both by the many instances of anticonvulsant intoxication seen during the epidemic and by the subsequent finding of epileptic patients who were receiving treatment with phenytoin but whose seizures had not been adequately controlled until the approximate time of the epidemic of anticonvulsant intoxication; since that time these patients had very much better or complete control of their epilepsy. Thus though inadequate levels of phenytoin in blood and tissue had been attained previously, in these latter patients, the increased phenytoin concentrations associated with the change of excipient may have improved control of their epilepsy.

Excipients have often been thought of as inert substances present in pharmaceutical preparations merely to allow their manufacture in a convenient form, but from the experience described here excipients may not always be biologically inert. Knowledge of this possibility should deter manufacturers from changing the excipient in their preparations, and should make the physician wary of changing from one brand of a particular drug to another. The theoretical possibility that the excipient in one pharmaceutical preparation might alter the metabolism of another drug administered simultaneously should also be considered.

\section{REFERENCES}

Balla, J. (1968). Medical fournal of Australia, 2, 480.

Eadie, M. J., Sutherland, J. M., and Tyrer, J. H. (1968). Medical fournal

of Australia, 2, 515.

Rail, L. (1968). Medical fournal of Australia, 2, 339.
Wallace, J. E. (1966). Fournal of Forensic Sciences, 11, 552.

\title{
Vascular Complications in Nephrotic Syndrome: Relationship to Steroid Therapy and Accelerated Thromboplastin Generation
}

\author{
A. P. MUKHERJEE, ${ }^{*}$ M.B., M.R.C.P.ED. ; B. H. TOH,* M.B., M.R.A.C.P. ; G. L. CHAN, † F.I.M.L.T. \\ K. S. LAU, $¥$ M.B., M.C.P.A. ; J. C. WHITE, $\$ M.B., F.R.C.PATH.
}

British Medical fournal, 1970, 4, 273-276

\begin{abstract}
Summary: Arterial thrombosis and renal vein throm$N$ bosis occurred in two men and one woman, respectively, treated with steroids for the nephrotic syndrome. Raised serum cholesterol occurred in one patient only. Though bleeding, clotting, and prothrombin times, as well as the platelet counts, were normal, the rate of thromboplastin generation was increased in all three patients. Adding heparin to the plasma of one patient slowed the rate, and suggested that the raised rate could be due to removal or suppression of such normal circulating coagulation inhibitors. The thromboplastin generation test seems to be useful in diagnosing and managing such hypercoagulable states, and may help in further investigations of their causes.
\end{abstract}

\section{Introduction}

Vascular complications in patients with nephrotic syndrome are an uncommon but serious problem. Though various pathogenetic mechanisms have been considered for these complications there is little agreement about their role. The present study was undertaken to determine the coagulation mechanism in three patients with occlusive vascular disease complicating the nephrotic syndrome. A series of patients without this complication was also studied, with particular reference to the effects of steroid therapy.

\section{Case 1}

A previously healthy 24-year-old Chinese man was admitted to hospital with puffiness of face and swelling of legs. Clinical examination and laboratory investigations showed features of nephrotic syndrome. He had low plasma protein, $3.5 \mathrm{~g} . / 100 \mathrm{ml}$; albumin, $0.65 \mathrm{~g} . / 100 \mathrm{ml}$; and serum cholesterol, $350 \mathrm{mg} . / 100 \mathrm{ml}$. Daily urinary protein excretion ranged from 5.3 to $13.0 \mathrm{~g}$. Bleeding and venous clotting times were normal; lupus erythematosus (L.E.) cell tests were negative. Percutaneous renal biopsy showed

\footnotetext{
- Lecturer in Medicine.

† Laboratory Assistant, Superscale.

₹ Professor and Head of Department of Pathology.

Senior Lecturer in Pathology.

Faculty of Medicine, University of Malaya, Kuala L.umpur.
}

features of proliferative glomerulonephritis. His oedema improved on $60 \mathrm{mg}$. of prednisolone daily but reoccurred three weeks after discharge because he neglected to take his tablets. After another three weeks in hospital he was discharged on $45 \mathrm{mg}$. of prednisolone daily. The erythrocyte sedimentation rate (E.S.R.) remained raised throughout, $88-116 \mathrm{~mm}$. in first hour (Westergren).

Two months later he was readmitted with femoral artery thrombosis. Right midthigh amputation was performed, and on examination the femoral artery and its branches were occluded. There was medial hyperplasia and intimal proliferation, but no evidence of arteritis or any atherosclerosis.

On coagulation study platelets were normal in number, morphology, adhesiveness, and aggregation; fibrinogen levels, prothrombin time, and thrombotest were also normal. The thromboplastin generation test (Biggs and Douglas, 1953), however, showed an accelerated pattern on two occasions (see Table and Fig. 1). The patient's plasma, and particularly the serum, produced an intermediate degree of acceleration when mixed with normal serum or plasma, respectively. At this time he had two weakly positive L.E. cell tests out of four, but subsequent tests had been negative. Complete clinical remission has since occurred with immunosuppressive therapy.

\section{Case 2}

A 35-year-old Chinese was admitted to hospital for swelling of the legs. He had had a similar illness when he was 10 years old. Features of the nephrotic syndrome were found on clinical examination and laboratory investigations. The serum cholesterol was very high at $950 \mathrm{mg} . / 100 \mathrm{ml}$. Total serum proteins were $4.2 \mathrm{~g} . / 100 \mathrm{ml}$. and albumin $2.0 \mathrm{~g} . / 100 \mathrm{ml}$. The daily urinary protein varied from 5 to $10 \mathrm{~g}$. The bleeding, clotting, and prothrombin times were normal; L.E. cell tests were negative on three occasions. No specific changes by light microscopy were seen in the renal biopsy specimen, and the nephrotic syndrome of "minimal change" type (Habib et al., 1961) was diagnosed. At discharge the patient was on $45 \mathrm{mg}$. of prednisolone daily. After being sympton-free for 10 months he was readmitted for exacerbation of the nephrotic syndrome. During this admission he developed substernal chest pain due to anterior myocardial infarction. Serum cholesterol ranged from 1,300 to $1,900 \mathrm{mg}$./100 ml. Coagulation studies showed no platelet abnormality; plasma fibrinogen levels, prothrombin time, and thrombotest were normal. There was, however, definite acceleration of thromboplastin generation on three occasions over a three-month period (see Table and Fig. 
Thromboplastin generation times of normal controls and nephrotic patients with and without vascular complications, and with and without prednisolone therapy. Mean times and ranges are given in seconds for the subsamples from one to six minutes

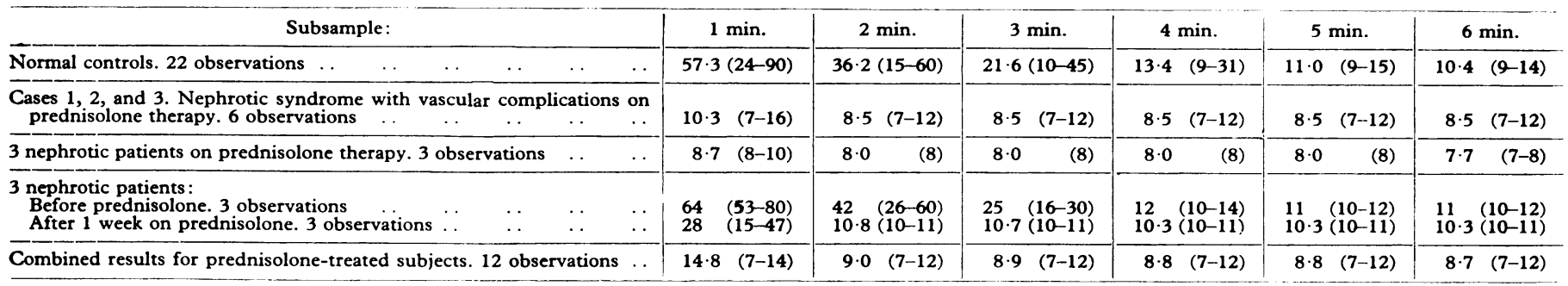

1). The antihaemophilic globulin concentration was $91 \%$ of normal on the last occasion. He recovered from the myocardial infarction and remained well for one year on steroids and cytotoxic drugs.

\section{Case 3}

A 28-year-old Chinese housewife was admitted to hospital with a history of recurrent fever and polyarthritis for three months, and dysuria, loin pain, and puffiness of the face for one week. On clinical examination and laboratory investigations she had all the features of nephrotic syndrome except a raised serum cholesterol, which was normal at $160 \mathrm{mg} . / 100 \mathrm{ml}$. Bleeding, clotting, and prothrombin times were normal; L.E. cell test was positive on seven occasions; E.S.R. was raised, being $94-132 \mathrm{~mm}$. in the first hour (Westergren). Intravenous pyelogram was normal. Percutaneous biopsy of the right kidney showed membrano-proliferative nephritis. At discharge she was on $40 \mathrm{mg}$. of prednisolone daily. After being symptom-free for one month she was readmitted with acute pain in the left loin. A repeat intravenous pyelogram revealed a non-functional left kidney considerably larger than that seen in the previous pyelogram. The right kidney was normal.

Eight days after admission she developed frank haematuria. A renal angiogram showed pronounced narrowing of the left renal artery. Small branches of the left renal artery were not visualized and there was no nephrogram phase on that side. Acute interstitial oedema and other features suggestive of left renal vein thrombosis were seen in the specimen obtained by percutaneous left renal biopsy. Her platelets level and function, and plasma fibrinogen, prothrombin time, and thrombotest were all normal. The thromboplastin generation test showed considerable acceleration of the rate of intrinsic thromboplastin production (see Table and Fig. 1). The patient's serum and to a lesser extent the plasma caused accelerated thromboplastin generation when mixed with normal plasma or serum, respectively. She improved considerably on steroid and immunosuppressive therapy, but a month later was readmitted with drowsiness and headache of one day's duration and died of cryptococcal meningitis.

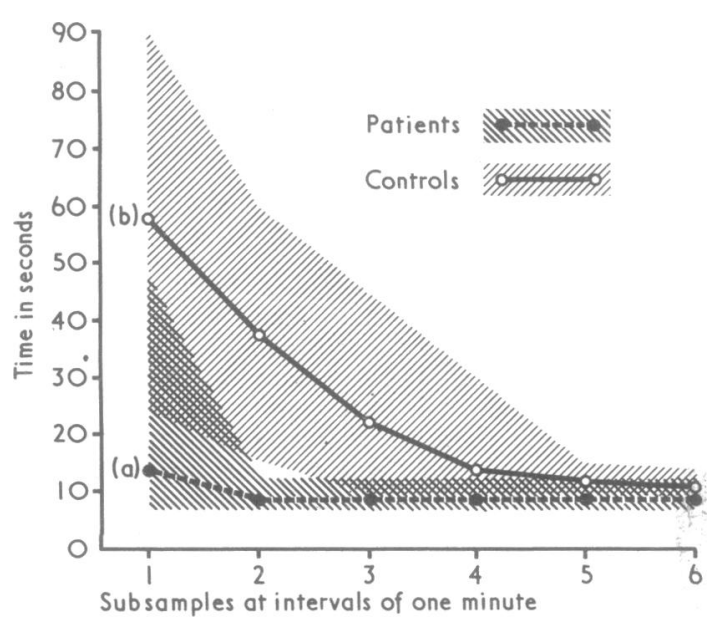

FIG. 1.-Ranges and means of thromboplastin generation times plotted to show: (a) the accelerated pattern in 9 nephrotic patients on prednisolone therapy ( 12 observations on 3 patients with vascular complications, 3 patients during therapy, and 3 patients one week after commencing prednisolone therapy, and 3 patients one week after commencing predn
therapy), and (b) the normal pattern for 22 control subjects.

\section{Rate of Thromboplastin Generation}

The rate of thromboplastin generation was accelerated on six occasions during the course of steroid therapy in the three patients described (see Table and Fig. 1). Three further nephrotic patients on steroid therapy but without vascular complications had a comparable degree of acceleration (see Table). The prothrombin time, thrombotest, clot retraction, and platelet counts were all normal. The fibrinogen varied from 160 to $430 \mathrm{mg} . / 100 \mathrm{ml}$. Platelet adhesiveness and aggregation were normal in the one patient tested.

Three more nephrotic patients were examined before and one week after starting prednisolone therapy. In all cases the initial normal thromboplastin generation test showed the accelerated pattern during therapy (see Table). All other values of the coagulation investigations, including platelet adhesiveness and aggregation, remained normal. In another nephrotic patient not treated with steroids thromboplastin generation was normal as were all other features of the coagulation mechanism. Of four non-nephrotic patients receiving prednisolone for various haematological conditions three had a normal thromboplastin generation test and one the accelerated pattern.

The pattern of accelerated thromboplastin generation in nephrotic patients receiving prednisolone therapy as compared with the normal controls is shown in Fig. 1. The maximum rate of thromboplastin generation is approached in the twominute subsample in the nephrotic subjects but in the fourminute subsample in the normal controls. The in-vitro addition of hydrocortisone succinate in amounts from 10 to $50 \mu \mathrm{g} . / \mathrm{ml}$. to normal adsorbed plasma had no effect on the rate of thromboplastin generation. The expected effect of heparin in retarding the rate of thromboplastin generation in normal plasma when added in amounts of from 2 to 64

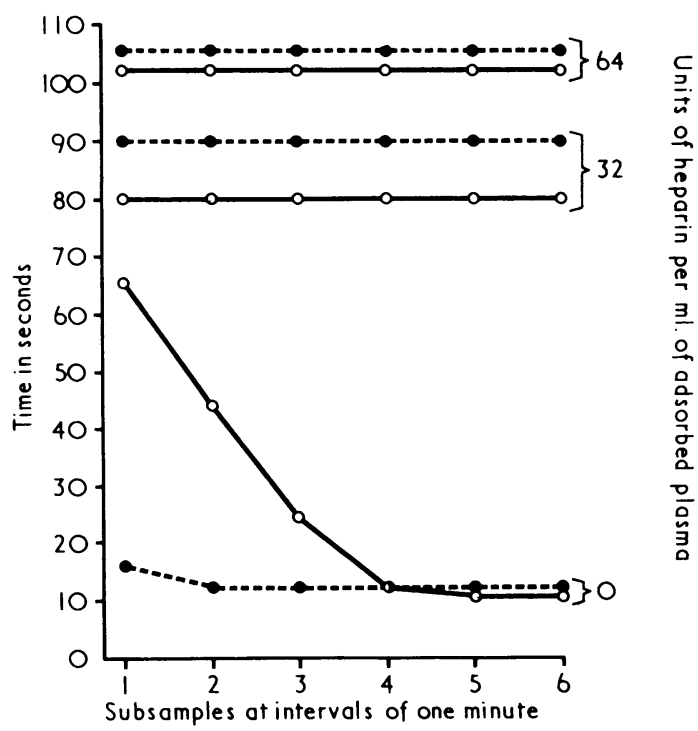

Fig. 2.-Effect of added heparin on the thromboplastin generation times of: $(a)$ normal control plasma $O-O(b)$ plasma of Case 2 with nephrotic syndrome on prednisolone therapy -1 
units $/ \mathrm{ml}$. is shown in Fig 2. Heparin produced a comparable degree of retardation when 32 and 64 units $/ \mathrm{ml}$. were added to the adsorbed plasma of Case 2, though the untreated plasma showed a definite acceleration of thromboplastin generation (Fig. 2); the antihaemophilic globulin concentration was $91 \%$. On chemical analysis the prednisolone content of the 5-mg. tablets given to these patients was only $4.1 \mathrm{mg}$. (82\%) and below the B.P. (1968) specifications of $90-110 \%$.

\section{Discussion}

Vascular complications and occlusive vascular disorder in the nephrotic syndrome have not often been discussed. Thrombosis of the great vessels, on the other hand, has been described (Gootman et al., 1964; Symchych and Perrin, 1965; Levin et al., 1967; Virabhak, 1967). Arterial thrombosis following femoral venepuncture has been reported by Goldbloom et al. (1957). Berlyne and Mallick (1969) stressed the importance of raised serum cholesterol level and an abnormality of lipid metabolism in nephrotic patients with myocardial infarction. The relation of arteritis and nephrotic syndrome has been discussed by Goodwin et al. (1969). Cerebral cortical venous thrombosis in the nephrotic syndrome was described by Nesson et al. (1963) and increased fibrinolytic activity in the renal venous blood of patients with chronic renal disease observed by Menon (1967). Activation of the first phase of coagulation in the nephrotic syndrome has been outlined by Becker (1968), with generation of thromboplastin and compensatory activation of the antithrombin system; in rabbit Masugi nephritis raised fibrinogen accompanied accelerated thromboplastin generation.

Hypercoagulation of the blood in patients receiving corticotrophin or cortisone has been described by Cosgriff et al. (1950); Adams et al. (1962) referred to thrombophlebitis of the leg veins in nephrotic patients receiving steroids, while Miller et al. (1969) noted cerebral infarctions leading to death and femoral artery occlusion in such patients. Chatterjea and Salomon (1954) described increased incidence of thromboembolic complications during corticotrophin and cortisone therapy. In a study of the clot-promoting action of steroid in high doses, antihaemophilic globulin increased while the whole blood coagulation, prothrombin and partial thromboplastin generation times decreased (Ozsoylu et al., 1962). These workers also observed the accelerated pattern of thromboplastin generation in these subjects. On the other hand, a deficiency of factor IX occurred among patients with nephrotic syndrome (Handley and Lawrence, 1967).

Though the exact mechanism leading to hypercoagulability is not known there is evidence of increased platelet adhesiveness, shortening of thromboplastin generation time, and faster platelet turnover (Murphy and Mustard, 1962). Spittell et al. (1960) observed accelerated formation of thromboplastin in 22 out of 69 patients with occlusive arterial and venous disease, and this phenomenon could be temporary or prolonged. Pascuzzi et al. (1961) and Spittell et al. (1961) postula ed the presence of a thromboplastin generation accelerator from their observations on the effects of artificially retarding the accelerated plasma thromboplastin generation time in such patients.

Dehydration may be a factor in the occurrence of venous thrombosis, but the cause for occlusive arterial disease is more complex. Among the possible factors which might cause these vascular complications are raised serum lipids and cholesterol, hypertension, arteritis, vascular spasm, vasculitis, and disturbances resulting in hypercoagulability. Vasculitis and arteritis are more likely to occur in patients with autoimmune disease. The third of our three patients had florid systemic lupus erythematosus, while the first gave two weakly positive L.E. cell tests at one period of his illness.
The histological material from these two patients, however, showed no active arteritis or vasculitis.

Barclay et al. (1960) considered dehydration, raised fibrinogen levels, altered fibrinolytic activity, and decreased renal blood flow in relation to renal vein thrombosis. These factors were not present in our patient with renal vein thrombosis (Case 3), and the serum cholesterol was normal. In our second patient, however, the serum cholesterol was definitely raised, and this might have made the occurrence of atherosclerosis more likely, and so lead to coronary thrombosis. Case 1 had mildly raised serum cholesterol, but no atheroma was evident in the thrombosed femoral artery. The common factor in all three cases is the accelerated rate of intrinsic thromboplastin generation. This appears to be associated with prednisolone therapy, since three other patients with the nephrotic syndrome receiving this therapy showed the same phenomenon; and in a further three the rate of thromboplastin generation changed from normal to abnormal when they were placed on prednisolone therapy, though none of these cases had thrombotic phenomena.

An accelerated pattern of thromboplastin generation seems to occur frequently in nephrotic patients treated with steroids, but to what extent this is associated with vascular thrombosis is not known. The frequency with which these two phenomena occur in patients with other diseases who are receiving steroid therapy is also unknown, but may be less than in patients with the nephrotic syndrome. Out of four cases investigated only one had an accelerated pattern, the other three being normal.

In experiments on the plasma from Case 2 the accelerated rate of thromboplastin generation could be slowed by adding heparin. In similar experiments using normal plasma heparin also retarded the rate of normal thromboplastin generation. This would suggest that the phenomenon of accelerated thromboplastin generation in these patients could be due to the removal or suppression of normal circulating coagulation inhibitor substances like heparin.

The effect of heparin in retarding the generation of thromboplastin has been extensively studied (Biggs and Douglas, 1953; Biggs et al., 1953; MacMillan and Brown, 1954; Douglas, 1956; Shanberge et al., 1959) but the exact point of action is still not clearly understood, and even less is known of its in-vivo activity. Though Cosgriff et al. (1950) failed to find evidence for suppression of heparin-like substances in the plasma of patients treated with corticotrophin or cortisone. Cortisone causes degranulation and suppression of mast cells (Stuart, 1951; Selye, 1965), which are the body's main source of heparin (Jorpes et al., 1937). Such an action could lead to deficiency of these anticoagulants and acceleration of the thromboplastin generation. McGraw et al. (1952) suggested that, though corticotrophin might initially lead to hyperheparinaemia by such means, hypoheparinaemia would occur when destruction of mast cells exceeded regeneration and the supply of heparin-carrier cells became exhausted. Cosgriff et al. (1950) indicated the potentially "prethrombotic state" produced by corticotrophin and cortisone in clinical situations demanding long-term therapy. Hence the thromboplastin generation test seems to be a useful guide to the diagnosis and management of this hypercoagulable state and to serve as a tool in further investigations of the mechanism of its causation.

This study is supported in part by funds from the U.S. Public Health Service Asia Grant No. AM11048-01.

We thank Dr. H. O. Wong and Dr. M. Somasundaram for allowing us to investigate patients under their care in the University Hospital, Kuala Lumpur; the department of medical illustration; and $\mathrm{Mr}$. Yeap Boon Chye, superintending pharmaceutical chemist, Government Pharmaceutical Store, for the prednisolone assay. One of us (J.C.W.) is in receipt of a Special Commonwealth Award. 
REFERENCES

Adams, D. A., Bernstein, D., and Maxwell, M. H. (1962). In Clinical Uses of Adrenal Steroids, ed. J. Brown and C. M. Pearson, p. 270. New York, Blakiston.

Barclay, G. P. T., Cameron, H. MacD., and Loughridge, L. W. (1960). Quarterly fournal of Medicine, 29, 137.

Becker, E. L. (1968). In Structural Basis of Renal Diseases, ed. E. L. Becker, p. 361 . New York, Hoeber.

Berlyne, G. M., and Mallick, N. P. (1969). Lancet, 2, 399.

Biggs, R., and Douglas, A. S. (1953). Fournal of Clinical Pathology, 6, 15.

Biggs, R., Douglas, A. S., and Macfarlane, R. G. (1953). Fournal of Physiology, 122, 554.

British Pharmacopoeia, 1968, p. 797. London, Pharmaceutical Press.

Chatterjea, J. B., and Salomon, L. (1954). British Medical fournal, 2, 790.

Cosgriff, S. W., Diefenbach, A. F., and Vogt, W., jun. (1950). American Fournal of Medicine, 9, 752 .

Douglas, A. S. (1956). Fournal of Clinical Investigation, 35, 533.

Goldbloom, R. B., Hillman, D. A., and Santulli, T. V. (1957). Pediatrics, 40, 450.

Goodwin, J. F., et al. (1969). British Medical fournal, 2, 359.

Gootman, N., Gross, J., and Mensch, A. (1964). Pediatrics, 34, 861.

Habib, R., et al. (1961). In Ciba Foundation Symposium on Renal Biopsy, ed. G. E. W. Wolstenholme and M. P. Cameron, p. 70. London, Churchill.

Handley, D. A., and Lawrence, J. R. (1967). Lancet, 1, 1079.

Jorpes, E., Holmgren, H., and Wilander, O. (1937). Zeitschrift für mikroskopisch-anatomische Forschung, 42, 279.
Levin, S. E., Zamit, R., and Schmaman, A. (1967). British Mcdical fournal,

McGraw, A. B., Margulis, R. R., and Brush, B. E. (1952). Archives of Surgery, 65, 81.

MacMillan, R. L., and Brown, K. W. G. (1954). Fournal of Laboratory and Clinical Medicine, 44, 378.

Menon, I. S. (1967). British Medical fournal, 2, 110.

Miller, R. B., Harrington, J. T., Ramos, C. P., Relman, A. S., and Schwartz, W. B. (1969). American fournal of Medicine, 46, 919.

Murphy, E. A., and Mustard, J. F. (1962). Circulation, 25, 114.

Nesson, H. R., Sproul, L. E., jun., Relman, A. S., and Schwartz, W. B. (1963). Annals of Internal Medicine, 58, 268.

Ozsoylu, S., Strauss, H. S., and Diamond, L. K. (1962). Nature, 195, 1214.

Pascuzzi, C. A., Spittell, J. A., jun., Thompson, J. H., jun., and Owen, C. A., jun. (1961). Fournal of Clinical Investigation, 40, 1006.
(19.,

Selye, H. (1965). The Mast Cells. Washington, D.C., Butterworths.

Shanberge, J. N., Sarelis, A., and Regan, E. E. (1959). Fournal of Laboratory and Clinical Medicine, 54, 501.

Spittell, J. A., jun., Pascuzzi, C. A., Thompson, J. H., jun., and Owen, C. A., jun. (1960). Proceedings of the Staff Meetings of the Mayo Clinic, 35, 37 .

Spittell, J. A., jun., Pascuzzi, C. A., Thompson, J. H., jun., and Owen, C. A., jun. (1961). Annals of Internal Medicine, 55, 765.

Stuart, E. G. (1951). Anatomical Record, 109, 351.

Symchych, P. S., and Perrin, E. V. (1965). American Fournal of Diseases of Children, 110, 636.

Virabhak, N. K. (1967). Fournal of the Singapore Paediatric Society, 9, 153.

\title{
Mixed Venous Oxygen Saturation in Relation to Cardiac Output in Myocardial Infarction
}

\author{
A. L. MUIR, ${ }^{*}$ M.R.C.P.ED. ; B. J. KIRBY, ${ }^{*}$ M.R.C.P. ; A. J. KING, ${ }^{*}$ M.B., CH.B. ; H. C. MILLER, † M.R.C.P.
}

British Medical fournal, 1970, 4, 276-278

\begin{abstract}
Cummary: Mixed venous oxygen saturations derived from measurement of mixed venous oxygen tension were compared with dye dilution cardiac output determinations in 26 patients with acute myocardial infarction. Mixed venous oxygen saturation was greatly reduced in patients with shock or failure complicating myocardial infarction. The level of oxygen saturation correlated with cardiac output determinations. The measurement of mixed venous oxygen saturation, which is relatively simple and does not require elaborate equipment, should be an important aid to the rational treatment of patients with low output states complicating acute myocardial infarction.
\end{abstract}

\section{Introduction}

An increase in cardiac output is one of the aims of therapy in acute myocardial infarction complicated by left ventricular failure or shock. Ideally such changes in cardiac output if they occur should be monitored, but in most units caring for such patients the special equipment and techniques required for estimating cardiac output are not readily available. Several reports have suggested that either central venous or mixed venous oxygen saturation is an adequate monitoring technique for assessing cardiac function and have correlated changes in venous oxygen saturation with the clinical status of the patients (Valentine et al., 1966; Goldman et al., 1968; Scheinman et al., 1969). The purpose of this paper is to assess the value of using mixed venous oxygen saturation as a measure of cardiac output in patients with differing grades of severity of acute myocardial infarction.

\footnotetext{
* Lecturer in Medicine, Department of Medicine, the Royal Infirmary, Edinburgh EH3 9YW.

† Medical Research Council, Research Fellow.
}

\begin{abstract}
These observations were made during the investigation and treatment of patients with acute myocardial infarction. Infarction was diagnosed by the W.H.O. (1959) criteria. An approximate estimate of the severity of the infarct was made by classifying the patients as (1) uncomplicated, (2) with left tricular failure, and (3) with cardiogenic shock. Left ventricular failure was diagnosed when there were widespread lung crepitations and dyspnoea in the absence of a history of bronchitis. Cardiogenic shock was diagnosed when pallor, cold skin, restlessness, and oliguria were present and the systolic blood pressure measured by sphygmomanometry remained below $90 \mathrm{~mm}$. $\mathrm{Hg}$.

Cardiac output was determined by a dye dilution technique in 26 patients ( 21 men and 5 women aged 43 to 76 years). Details of our investigational techniques in patients with acute myocardial infarction have been reported (MacDonald et al., 1967). Mixed venous blood samples were obtained from a small "float-in" catheter (Portex, O.D. 0.75 mm.). With this catheter we were able to sample at rates of about $1 \mathrm{ml}$. per minute. The position of the catheter in the pulmonary artery was determined by an adequate pulmonary arterial trace. Samples were obtained immediately before determination of cardiac output.

Blood samples were analysed for oxygen and carbon dioxide tension in a cuvette combining $\mathrm{O}_{2}$ and $\mathrm{CO}_{2}$ electrodes (Instrumentation Laboratories Inc., Boston, Model 113), pH determinations were made with the same equipment. The accuracy of these oxygen and carbon dioxide electrodes in our laboratory has been described (Flenley et al., 1967). Oxygen saturations were derived from the data of Severinghaus (1966). The oxygen-carrying capacity of the
\end{abstract}

Methods blood was determined by a spectrophotometric technique. In some patients total oxygen content was measured by the method of Van Slyke and Neill (1924). 